\title{
Analisis Pemilahan Persampahan Berskala Individual Rumah Tangga (Studi Kasus Kelurahan Panarung, Kecamatan Pahandut, Kota Palangka Raya, Kalimantan Tengah)
}

\author{
${ }^{1}$ Ibrahim Sanusi, ${ }^{2}$ Hendra Cahyadi, ${ }^{2}$ Rida Respati \\ ${ }^{1}$ Alumni Program Studi Teknik Sipil Universitas Muhammadiyah Palangkaraya \\ ${ }^{2}$ Dosen Program Studi Teknik Sipil Universitas Muhammadiyah Palangkaraya
}

\begin{abstract}
ABSTRAK
Saat ini timbulan sampah di Kelurahan Panarung tidak sebanding dengan jumlah TPS yang ada. Penelitian ini membahas tentang jalan keluar dari masalah itu dengan menerapkan sistem pemilahan sampah di rumah tangga. Metode penelitian ini menggunakan metode penelitian deskriptif yang memaparkan hasil kuisioner menggunakan grafik. Pada penelitian ini sebagai langkah awal dilakukan penentuan lokasi sampel sebanyak 3 lokasi yang luas wilayahnya masing-masing sebesar $250.000 \mathrm{~m}^{2}$. Dari masing-masing lokasi diambil $1 \mathrm{RT}$ yang menjadi target responden untuk penelitian ini. Kemudian jika memang lebih dari 50\% responden menyetujui untuk memilah sampah dari rumah tangga, dibuatlah pola pengelolaan yang tepat untuk meredam sampah yang mereka produksi guna mengurang beban yang akan di terima oleh TPS-TPS terdekat. Kemudian dalam menghitung potensi redaman sampah menggunakan metode dari Standar Nasional Indonesia (SNI) yaitu SNI 19-3964-1995. Hasil penelitian menunjukan bahwa masyarakat yang bermukim di Kelurahan Panarung menyetujui adanya peraturan wajib pilah sampah dari tangga. Pola pengelolaan yang cocok untuk wilayah tersebut adalah pola pengelolaan sampah berbasis Bank Sampah. Hal ini disebabkan masyarakat di Kelurahan Panarung kurang memliki waktu dalam mengelola sampahnya sendiri. Pengelolaan berbasis bank sampah tersebut memiliki potensi redaman sampah sebesar $66,684 \%$ dari jumlah total timbulan yang diproduksi.
\end{abstract}

Kata kunci: pengelolaan, sampah, pemilahan, redaman

\section{PENDAHULUAN}

Kota Palangka Raya dengan luas 2.400 $\mathrm{km}^{2}$ dan terdiri dari 44 kelurahan yaitu salah satunya adalah Kelurahan Panarung, kelurahan tersebut adalah salah satu daerah yang memiliki jumlah penduduknya padat jika dibandingkan dengan kelurahankelurahan lainnya. Berdasarkan data dari Dinas BAPPEDA Kota Palangka Raya tahun 2012 saja jumlah penduduk di kelurahan Panarung adalah 21.172 Jiwa. Atas alasan peningkatan penduduk setiap tahunnya otomatis berakibat meningkatnya juga sampah yang dihasilkan dan kurangnya sarana dalam menunjang pelayanan sampah yang ada di daerah Kelurahan Panarung yang di akibatkan oleh kurangnya lahan untuk di jadikan TPS dan banyaknya TPS yang ditutup oleh warga adalah masalah utama dalam pelayanan persampahan kota khususnya Kelurahan Panarung.

Karena masalah tersebut maka salah satu jalan keluar yang cocok dalam permasalahan ini adalah meredam atau mengurangi dari hulu sampah yaitu masyarakat sebagai produsen sampah, dengan cara pemilahan persampahan berskala individual rumah tangga. Secara garis besar 
pemilahan persampahan ini berkonsep pemilahan sampah organik dan anorganik yang nantinya akan diolah dengan metode yang berbeda pula antara organik dengan anorganik dan pengelolaannya pun berbeda antara konsep pengelolaan individu maupun komunal.

Alfiandra (2010) melakukan penelitian di Semarang, Jawa Tengah, menyimpulkan bahwa efektifitas pengelolaan sampah dalam program 3R dapat disimpulkan bahwa pelaksanaan program $3 R$ berjalan secara baik, efektif, efisien, dan optimal. Dengan adanya pengelolaan sampah $3 \mathrm{R}$ terjadi perbaikan atau peningkatan dalam pengelolaan sampah, pengelolaannya semakin baik dibanding sebelum dilakukan program 3R, hal ini dikarenakan sampah telah dipilah oleh masyarakat untuk didaur ulang menjadi barang yang berguna sehingga penumpukan sampah di Kelurahan Ngaliyan dan Kalipancur dapat berkurang.

Ayu Artiningsih (2008), melakukan penelitian dengan studi kasus Jomblang di Kota Semarang, Jawa Tengah. Dalam penelitiannya dengan menyimpulkan bahwa pengelolaan sampah rumah tangga berbasis masyarakat dapat mereduksi timbulan sampah yang dibuang. Berdasarkan hasil analisis observasi, komposisi timbulan sampah di Jomblang adalah sampah organik $50.75 \%$ plastik $17.14 \%$, kertas $19.42 \%$ dan kaca/logam $12.70 \%$. Kemudian, dalam pengelolaan sampah rumah tangga berbasis 3R di RT.09, RW.XI Jomblang sudah melakukan pengomposan dan pemilahan, sampah rumah tangga dipilah sesuai jenisnya anorganik dan anorganik kemudian sampah organiknnya kemudian dijual dan kompos yang sudah jadi dipakai untuk menyuburkan tanaman masing-masing dalam rumah tangga, sehingga pengelolaan sampah rumah tangga yang dilakukan oleh warga Jomblang sudah mengurangi beban TPS, TPA maupun lingkungan.

Secara garis besar pengolahan sampah organik yang nantinya akan di kelola dengan pendaur ulangan menjadi kompos sedangkan sampah anorganik nantinya akan di tas dll. Dengan demikian sampah yang ada di hulu dapat mengurang dan masalah terhadap kekurangan jumlah TPS dapat teratasi dan juga mengurangi juga timbunan sampah yang ada di TPA sehingga membantu pula pemerintah dalam konteks permasalahan penanganan sampah-sampah yang ada di Palangka Raya. Oleh karena itu dalam penelitian ini akan dilakukan analisis pemilahan persampahan individual rumah tangga dengan tujuan untuk mengetahui representasi pengelolaan sampah dengan konsep pemilahan persampahan individual rumah tangga di Kelurahan Panarung.

\section{METODE PENELITIAN}

Metode penelitian ini mengacu pada diagram alir seperti pada Gambar 1 berikut.



Gambar 1. Diagram Alir Penelitian

\section{HASIL DAN PEMBAHASAN \\ Sistem Pengelolaan Persampahan}

Pengelolaan persampahan untuk wilayah Kelurahan Panarung saat ini memang kurang berjalan dengan baik. Hal ini dapat dilihat dari banyaknya timbunan sampah yang menumpuk pada setiap harinya, jika hal tersebut terus saja dibiarkan maka akan mengakibatkan terjadinya kerusakan dan pencemaran lingkungan.

Secara umum pengelolaan sampah di perkotaan dilakukan melalui 3 tahapan kegiatan, yakni: pengumpulan, pengangkutan, dan pembuangan akhir. Pengumpulan diartikan sebagai pengelolaan sampah dari tempat asalnya sampai ke tempat pembuangan sementara sebelum menuju tahapan berikutnya. Pada tahapan ini digunakan sarana bantuan berupa tong sampah, bak sampah, peti kemas sampah, gerobak dorong, 
maupun tempat pembuangan sementara. Di Kelurahan Panarung sendiri untuk masalah persampahan juga menjadi kendala yang harus dihadapi setiap harinya. Dengan meningkatnya pertumbuhan jumlah penduduk setiap tahunnya maka semakin bertambah pula jumlah sampah yang diproduksi, mulai dari sampah rumah tangga, toko, dan limbah industri. Apabila kesadaran masyarakat tidak mulai ditingkatkan mengenai sampah, maka pencemaran lingkungan khususnya di Kelurahan Panarung tidak akan terselesaikan.

Untuk saat ini pengelolaan persampahan di Kelurahan Panarung melalui 3 tempat sampel yang saya teliti ada warga yang memang sudah melakukan pemilahan ada juga yang belum melakukan pemilahan padahal pemerintah kota sudah terangterangan untuk menghimbau masyarakatnya untuk memilah sampah di rumah tangga.

\section{Tingkat Pengetahuan Masyarakat Tentang Pemilahan sampah}

Berdasarkan hasil kuesioner dari 51 reponden yang sampelnya di ambil secara acak dengan 3 daerah sampel yang sudah di tetapkan, untuk tingkat pengetahuan masyarakat tentang pemilahan sampah di rumah tangga dapat dilihat pada Gambar 2 sebagai berikut:

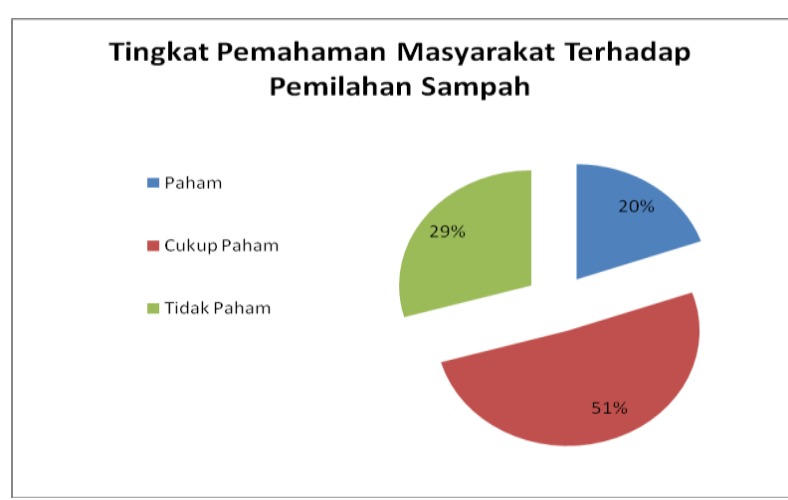

Gambar 2. Grafik Tingkat Pemahaman Masyarakat Pemilahan Sampah Rumah Tangga

Berdasarkan Gambar 2 diketahui bahwa responden yang menyatakan paham tentang pengelolaan sampah dengan cara pemilahan ada sebanyak $20 \%$ responden atau sebanyak 10 orang responden, sedangkan yang cukup paham tentang pengelolaan sampah dengan cara pemilahan ada sebanyak $51 \%$ responden atau sebanyak 26 orang responden, dan sisanya $29 \%$ responden atau sebanyak 15 orang mengatakan bahwa tidak paham tentang pengelolaan sampah dengan cara pemilahan.

Untuk itu, sebagian besar masyarakat yang bermukin di daerah RT.02/RW.VIII (Jl. Ramin III, Jl.Demak), RT.04/RW.XIV(Jln. Brokoli, Jln. Wortel), RT.03/RW.X (Komp. Bandara Estate, Jln. Adonis Samad) menyatakan mereka cukup paham dengan apa itu pemilahan sampah, akan tetapi jika suatu saat pemberlakuan pemilahan ini di jalankan hendaknya pemerintah sebagai fasilitator ataupun sebagai pengelola persampahan melakukan penyuluhan tentang pemilahan sampah sebelum pemberlakuan itu dilakukan karena mayoritas masyarakat hanya cukup tahu tentang pemilahan tersebut sehingga nantinya pemberlakuan aturan tersebut berjalan secara maksimal.

\section{KESIMPULAN}

Masyarakat yang bermukim di Kelurahan Panarung menyetujui adanya peraturan wajib pilah sampah dari tangga. Pola pengelolaan yang cocok untuk wilayah tersebut adalah pola pengelolaan sampah berbasis Bank Sampah. Hal ini disebabkan masyarakat di Kelurahan Panarung kurang memliki waktu dalam mengelola sampahnya sendiri. Pengelolaan berbasis bank sampah tersebut memiliki potensi redaman sampah sebesar $66,684 \%$ dari jumlah total timbulan yang diproduksi.

\section{DAFTAR PUSTAKA}

Dinas BAPPEDA Kota Palangka Raya. 2012. "Palangka Raya Dalam Angka", Palangkaraya.

Hadiwiyoto, S, 1983, Penanganan dan Pemanfaatan Sampah, Yayasan Idayu, Jakarta.

Kartikawan, Y., 2007, Pengelolaan Persampahan. Jurnal Lingkungan Hidup. Yogyakarta

Kodoatie, R., 2005, Manajemen dan Rekayasa Infrastruktur, Pustaka Pelajar, Yogyakarta.

Rao,1996, Measuring Consumers Perceptions Throught Factor Analysis. The Asian Manager 
